\title{
パイロット操船からみた針路不安定の許容限界 に関するシミュレータスタディ
}

\author{
小 瀬 邦 治* ・中 谷 辰五郎** \\ 信 川 孝 司***・中 村 祐 三***
}

Simulator Study on an Allowable Limit of Directional Instability

of Ships from the View-Point of Marine Pilots

Kuniji KOSE, Tatsugoro NAKATANI,

Takashi NOBUKAWA and Yuzo NAKAMURA

\begin{abstract}
The Japanese Pilots' Association has listed out a significant number of ships with extremely poor maneuverability. The ships are under operation in ports and waterways near Japan and dangerous experiences happened on such ships have been pointed out by the association. These show us an urgent necessity of the maneuverability standards which are the minimum requirements in maneuverability of ships.

To evaluate relations between the maneuverability and the operational safety from the viewpoints of marine pilots, simulation studies were carried out as a cooperated program between the Japanese Pilots' Association and Hiroshima university. Maneuvering simulations of berthing in some port and passing though a curved narrow channel were conducted by pilots on the Harbor Maneuvering Simulator of Hiroshima University.

The difficulty was assessed by the pilots. The results of performed maneuvers were carefully examined and the relation between both results was also confirmed. The allowable instability limit estimated from the present simulator studies is finally reported.
\end{abstract}

は じめに

最近, 船が最低限, 持つべき性能を明確にし, 基準化しょうといら立場から, 種々の研究がなされている。こ の操縱性能基準を巡る議論に重要な問題提起をしたのが，日本パイロット協会の操䊮性能不足船りストであった。 操船のベテランであるパイロットが不安を覚えるような針路不安定船が相当数, 運航されていることは安全上大 変に深刻な問題であり, パイロット協会では操綎性に関する小委員会を設置し, 実船の性能把握と, それと操船 の難易度との関連に関する調査を行っており，その結果は別に報告される筈である(1)。しかし，パイロット業務 の中で実施する操縦性能調查は時間的, 場所的制約から限界がある。

\footnotetext{
* 正会員 広島大学工学部（广724 広島市西条町下見）

** 正会員 広島大学大学院工学研究科（广724 広島市西条町下見）

*** 正会員 日本パイロット協会（テ102 千代田区料町 4-5 海事センタービル）
} 
他方，広島大学では操船シミュレータを開発し(2)，港内操船の基本パターンである要素操船に和ける針路不安 定の許容限界を検討をしている(3)。このような操船シミュレーションの手法を用いると, 多分に単純化された航 行環境の下ではあるが，既知の性能の船に対する操船難易度の系統的な調査が可能になり，上述の実船調査の搦 点を補らに役立つ。

そこで，パイロット操船という立場から，針路不安定の許容限界に関するシミュレータスタディを共同して実 施した。操船が困難になりやすいと考えられる航行環境をパイロットの経験から摘出し，入港着栈と狭水路，漁 労水域の通過という操船シナリオを制作した。このシナリオに従い，ハーバー及びベイパイロットによる操船シ ミュレーションを行い, パイロットの評価した操船の難易度を聴取した。また，操船の結果ををとめ，この困難 度との相関を調へ，最終的に針路不安定の許容限界について検討した。以下，本研究について要約して報告する。

\section{1. 実施した操船シミュレーションの概要}

以下，操船シミュレーションの概要を紹介する。

(1) 供試モデル

このシミュレーションでは, MMG型の操綎運動の数学モデルを用い, 約10度の不安定ループ幅を持っている 初期のVL C C を母船型とした。この船の流体力特性は拘束操縦性試験をべースとし, 舵特性は類似船型の実績 から求めた。このVLCCの数学モデルを単に時間スケールを变更する形で, 船長約 $140 \mathrm{~m}$, 排水量約 2 万トン の船に換算した。そこで, 通常の 2 万トンクラスの船に較べて, 結果的には主機馬力が相対的に小さい特性を持 つと考えられる。このモデルの舵面積を変更して,ループ幅が $5^{\circ}, 7.5^{\circ}, 10^{\circ}, 15^{\circ}$ のシリーズモデルを作った。

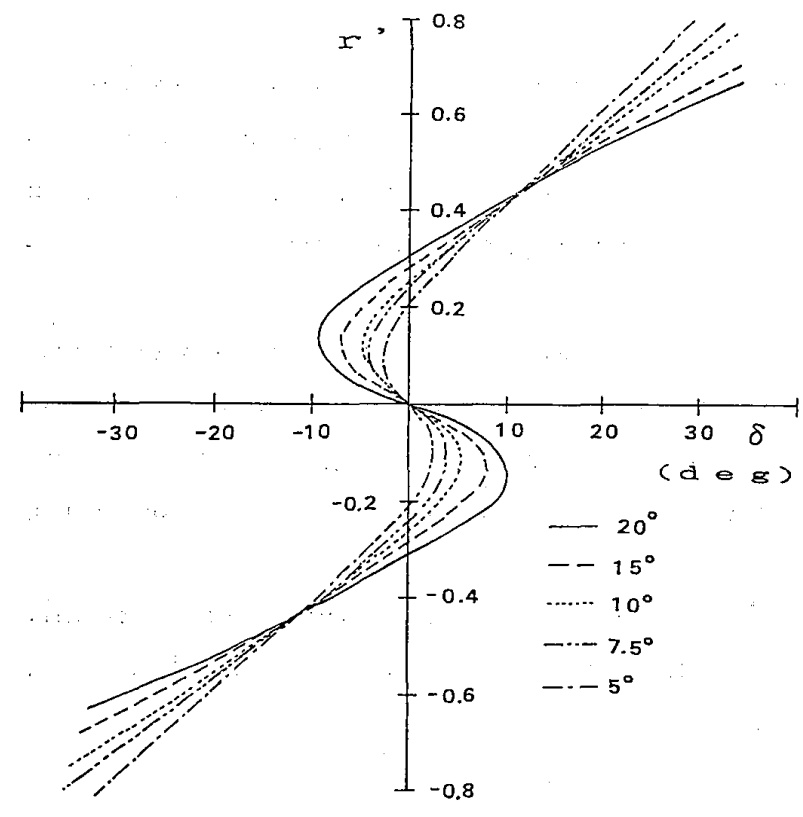

図 1 供試モデルの定常旋回特性 これらのモデルの定常旋回特性を，図1に示す。な お，入港時の停止，横移動の局面では，通常のMMG モデルから，低速時の操縦運動数学モデルに次第に切 り替えている。

（2）想定シナリオ

操船のシナリオを決めるに当たり，パイロットの側 から, 操船が困難な典型的な局面として, (1)狭水路の 通過，(2)検疫錨地への投鉷，(3)港内での岸壁間のシフ ト，(4)漁網の展開された海域の通過等が摘出された。 針路不安定船の運動性能と操船法から，その局面でな ぜ操船が困難になるかを想定し，これらの操船の局面 を次の 2 つの操船シナリオに集約し，シミュレーショ ンに供した。

(a) 狭水路通過操船シナリオ

通常航行中，パイロットは針路の指示を操舵員に与 え，船を目的の方向に誘導することができる。しかし， 湾曲した狭水路などでは，旋回半径を必要な大きさに 保らつつ, 時々刻々の方位を制御する必要がありこ

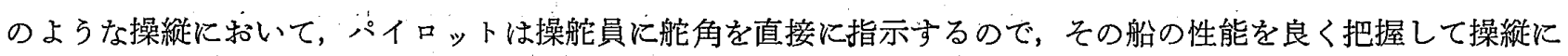
当たる必要がある。こうした場合，その船がパイロットが想像しているよりも著しく悪い場合，あるいは，パイ ロットが適切な判断をするのが困難になるほどに性能が悪い時, 操船の困難が生じる。

ま゙た，地形などに関しては，パイロットは予め情報を収集しておき，操船法を想定することができる。しかし， 漁網などの仮設物はその近傍に至って初めて情報が与えられるものであるから，臨機応変な操船指揮が要求され る。そのような操船を強いる意味で，漁網を配置した海域の通過を考えることにした。

岸壁への接近の場合, 曳船の支援を得て操船が行われる。しかし，港湾外の錨地への接近や停船の場合には， 自力操船が要求される。この場合には, 精度は㛜しくないが, 減速しながらの船位誘導を要求される。 以上のよらな操船を想定して，狭水路通過操船のシナリオを作成した。想定した操船のシナリオは次の通りで 


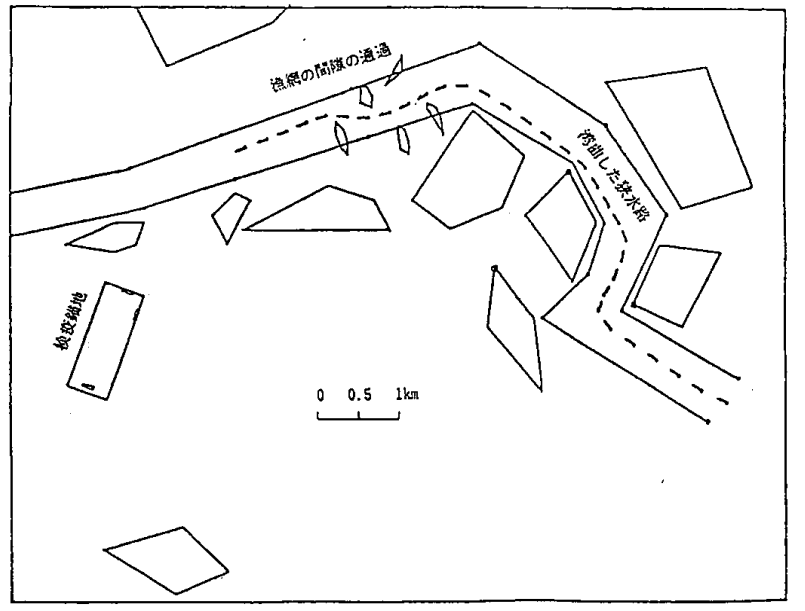

図 2 狭水路通過操船シナリオで用いた狭水路モデル （湾曲した狭水路一漁網の間隙の通過一検疫錨地）

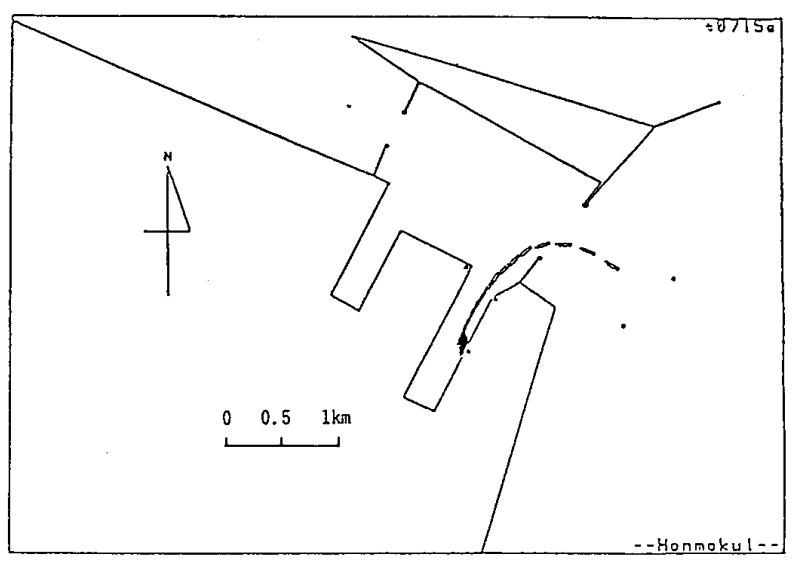

図 3 入港操船シナリオで用いた港湾モデル

ある。

(1) 想定水路：来島海峡に類似した，図 2 に示す模擬海陝を，いくつかの島，灯台，標識ブイなどで構成した。 また，水路通過後には，水路部を相当に覆ら形で漁網が展開されている状沉を設定している。ここを通過後， 航路を航行し，検疫錨地に停船することにしているが，今回のシミュレーションでは，この部分は時間の関係 で省略した。

(2) 操縱性能：同僚のパイロットより，本船は針路安定性が良くないとの情報が提供されているが，詳細は操船 者には不明である。

(3) 水路, 外力条件: 風速約 $10 \mathrm{~m} / \mathrm{s}$, 多少の波あり。潮流は皮いでいる。

(4) 漁網：海峡通過後の航路上に漁網が張られているとの情報が提供されている。

(b) . 入港着栈操船シナリオ

針路不安定船の操船に打いては, 一定船速航行中以上に，減速中は舵効きの低下と安定性の劣化が顕著である から，入港着栈操船のシナリオを想定した。減速中の保針，変針の難易度の研究によると，操舵員による保針に 関しては減速中も一定速度の場合とあまり違わないが，減速中の変針は顕著に困難になると指摘されている。そ こで, 減速しつつ, 変針するよらな入港操船の局面を考えた。

(1) 想定港湾：図 3 に示す模擬横浜港本牧埠頭にアプローチの後, 着栈する。

(2) 操綎性能：同僚パイロットより，本船は針路安定性が良くないと言う情報が提供されているが，詳細は操船 者には不明である。

(3) 港湾の外力条件：外乱無し

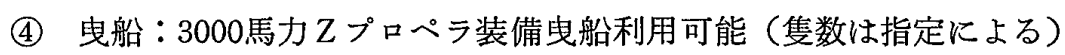

(5) 着栈速力距離表示装置 : 使用可能

(3) シミュレーションの実施要領

狭水路通過と入港着栈のシミュレーションに際しては，それぞれ日本パイロット協会のベイ及びハーバーパイ ロットが操船指揮を担当した。ほとんどのパイロットはシミュレータは未経験であったから，シミュレータに馴 れる意味で, 最初にファミリアライゼーションシミュレーションを実施し, その後に, 不安定度の異なる供試モ デルをランダムに設定した。狭水路通過操船シナリオの場合, 時間の関係上, 針路不安定の程度が軽いループ全 幅が 5 度の場合をファミリアライゼーションとして用いた。表 1 はシミュレーションに参加したパイロットとそ れぞれに対する供試モデルの実施順序を示す。多数のシミュレーションを実施した狭水路通過操船の場合，ルー プ全幅が $7.5^{\circ}, 10^{\circ}, 15^{\circ}$ のシミュレーションはランダムに順序を配置している。シミュレーションを重ねるに 従って，針路不安定な船の特性やシミュレータに馴れることが予想され，その程度を把握するための配慮である。 シミュレータには, 通常の航海計器のほか, レーダに替わる情報をC R T上に表示し, パイロットの要請に従 
表 1 操船シミュレーションに参加した パイロットに対する供試モデル の実施順序

\begin{tabular}{|c|c|c|c|c|}
\hline \multirow{2}{*}{ パイロット } & \multicolumn{4}{|c|}{ 供試モテル } \\
\hline & 1 回目 & 2 回目 & 3 会目 & 4 回目 \\
\hline A パイロット & $5^{\circ}$ & $10^{\circ}$ & 7. $5^{\circ}$ & $15^{\circ}$ \\
\hline B パイロット & $5^{\circ}$ & $15^{\circ}$ & 7. $5^{\circ}$ & $10^{\circ}$ \\
\hline C パイロット & $5^{\circ}$ & $10^{\circ}$ & $15^{\circ}$ & 7. $5^{\circ}$ \\
\hline D パイロット & $5^{\circ}$ & 7. $5^{\circ}$ & $10^{\circ}$ & $15^{\circ}$ \\
\hline E バイロット & $5^{\circ}$ & $15^{\circ}$ & $10^{\circ}$ & 7. $5^{\circ}$ \\
\hline F パイロット & $5^{\circ}$ & 7. $5^{\circ}$ & $15^{\circ}$ & $10^{\circ}$ \\
\hline
\end{tabular}

価が得られた。

以上を総合すると，パイロットの立場から許容される針路不安定の範囲を求めるという今回のシミュレーショ ンの目的から考光, 必要最小限のシミュレータ性能は確保できたと判断される。このシミュレータの設計, 制作 に際しては，操縦室の空の近くに大型スクリーンを配置し，下方にも広い視界を確保し，入港着栈操船の臨場感 に配慮したが，この目的は十分に達成したようである。

\section{2. 針路不安定度之操船の難易の相関に関する調査結果}

\section{1 調 查 概 要}

今回, 入港着栈之狭水路通過操船シナリオの内, 主力として系統的に実施したのは後者である。入港着栈操船 は減速状態の劣化した操縦性能の評価が主目的であり，そのシミュレーション例を前述の図 3 の中に示す。船首 尾の栈橋からの距離, 接近速力, 前後位置を表示する離着栈情報表示パネルの利用等もあり, 入港着栈の模様は らまく再現できたようである。しかし，今回の限られた調査例で針路不安定が操船に及ぼす影響を把握するには 至らなかった。この操船では一度, 大きな回頭をするが, この際には操縦性能とともに, パイロットの判断の適 否が操船の結果を大きく支配すること，岸壁前面迄のアプローチの際には本船固有の性能の他に曳船の影響が大 きいこと, 外力を加えていないために操船が容易であった等で, 操船の自由度が相当に大きく, 性能限界の把握 が困難だったものと考えられる。今後の系統的な調查を待って，入港着栈時の問題は検討することにしたい。

他方，狭水路通過操船の場合は航路の湾曲に従って，長い間，継続的に運動を制御する必要があるから，船の 性能が平均化した形で把握でき，針路不安定度と操船の困難度との関係を把握しやすいようである。以下，この 操船を中心にシミュレーション結果を報告する。

本研究では，これらの操船の結果を次の 3 つの立場から整理してみる。つまり（1) 操船者に対するアンケー ト調査から，シミェレーションに参加したパイロットがどの様な，どの程度の困難を感じたかを整理する。これ は言うなれば，供試モデルの操縦性能に対するパイロットの主観的な評価である。続いて，(2) 水路通過のため に使用した舵角とか，船位のばらつきとかの操船結果に，針路不安定の程度がどのような影響を与えているかを 整理する。これは，操船結果の客観的な評価となろう。そして最後に，(3) 両者の相関を調べることであり，両 者の間によい相関があれば，これらの評価結果に信頼性があることになる。

さて, 以上のような操船シミュレーションの結果は, 外力や航行環境の状況, 視界等を通じて与えられる情報, 緊張感等の違いを考慮して評価する必要があろう。シミュレータスタディにおいては，そこで得られた結果が実 際の世界の経験といかに対応しているかに関するValidation が重要である。このための方法として，1）実際 と同様なシミュレーションを行う, (2) シミュレーションで得られた操船の困難度の評洒を, パイロットの経験 で実際の操船に括ける評価に置き換えてもらう，(3) 実際の船に対する調査とシミュレーションに和ける評価の 結果を比較し，換算の尺度を得る，換言すると，一種の Calibration を行うことが大切と考觉られる。今回のス タディでは，さしあたり，(1)の方法は断念し，(2)の方法を取り入れることにした。また，日本パイロット協会で 
は操縦性能と操船の困難度に関する実船調查を進めて おり，(3の方法もいずれ試み得ると期待される。この (2) と(3)の方法は，パイロットの操船困難度評洒の尺度 の Calibration を試み, シミュレーションの結果を実 世界の経験に換算しようとするものである。

2.2 供試モデルの性能に関するパイロットの評価 パイロットに対する船の性能に関する質問事項は表 2 に示す通りであり，(1)としてシミュレーションシ ナリオのような操船にこのモデルが耐えられるかを， (2)として，一般的な操船局面を考慮して，このモデ ルの性能が耐光られるかを聞いている。以下，アンケ 一ト結果を紹介する。このアンケートに関する回答の 集計結果は表 2 に示す。

（1）ほとんぞのパイロットが操船シミュレータによ る操船は初めての経験であるから, シミュレーショ ンに対する不慣れが評価に関連している可能性があ る。この点をチェックできるように，2 回目から 4 回目のシミュレーションに括いては，モデルの設定 順序をランダムにして敃り，パイロットによる評価点を試験順序毎に平均化すると，順序あるいは馴れの影響 がわかる。この結果から，基本的には，順序あるいは馴れの影響は特にないと指摘できる。

（2）シミュレーションに供したモデルの性能とパイロットの評価の関連については，一人だけ， $7.5^{\circ}$ と $10^{\circ}$ の 評価が本来の性能と逆になっているのを除くと, 残りは全て, 正確に対応している。これから,パイロットは 大変, 正確に供試モデルの性能を把握しながら操繸していたことがわかり, 今回のシミュレーションの信頼度 が確認できる。

（3）このシナリオの操船に耐えられるかとの質問については，50の場合に十分，まあまあ，やや不十分が各 2 人ずつとなっているが， $15^{\circ}$ の場合には危険，不十分が各 2 人，まあまあとやや不十分が各 1 人となって特り， $5^{\circ}$ 程度ならなんとか許容できるが， $7.5^{\circ}$ あるいは $10^{\circ}$ 幅では不十分といら指摘が主力となる。

（4）一般的な操船に耐えられるかという質問に関しては，5゚のルフプ幅の場合には，総じて「まあまあ」とら い評価であるが，7.5ではやや不十分という評価が主力となり，10では不十分，危険という評価がでてきて いる。

（5）シナリオの操船と一般的な操船に耐えられるかといら両質問に対する回答は，当然ながら，後者の方が厳 しい評価になっている。狭水路航行中のシミュレーションにもかかわらず，潮流の影響を考㝋ていないとか， 遭遇船舶が無いとかの条件を設定しているのであるから，現実の操船はシナリオよりも困難で，性能評価も厳 しくならざるを得ないと考えられる。今後より現実に近づけたシミニレーションを企画する必要性を示す結 果である。 パイロットから具体的に指摘された事項の詳細なリストアップは省略するが，概略，次の指摘を得た。

(1) 船が 2 万トンと小さいが, 操縦性能不足船リストの主力を占める 5 万トンの船になると, 通過できたかどう か心配だ。

(2) 潮流が入っていないが，実際は相当に強い影響を受ける。

(3) 遭遇船があったら難しい。相手がこちらの行動をどう理解するか不安である。

(4) 当て舵が効かない。結局，ハードを発令することになる。

総じていうと, 今回のシミュレーションで想定した操船の局面は, 実際よりも簡単であり, 船の大型化, 高速 化，外力条件の現実化等を考慮したシナリオ開発が必要になる。

2.3 操船シミュレーション結果の評価

続いて，パイロットによって実際に操船された結果について検討する。操船結果の評価においては，例えば， 


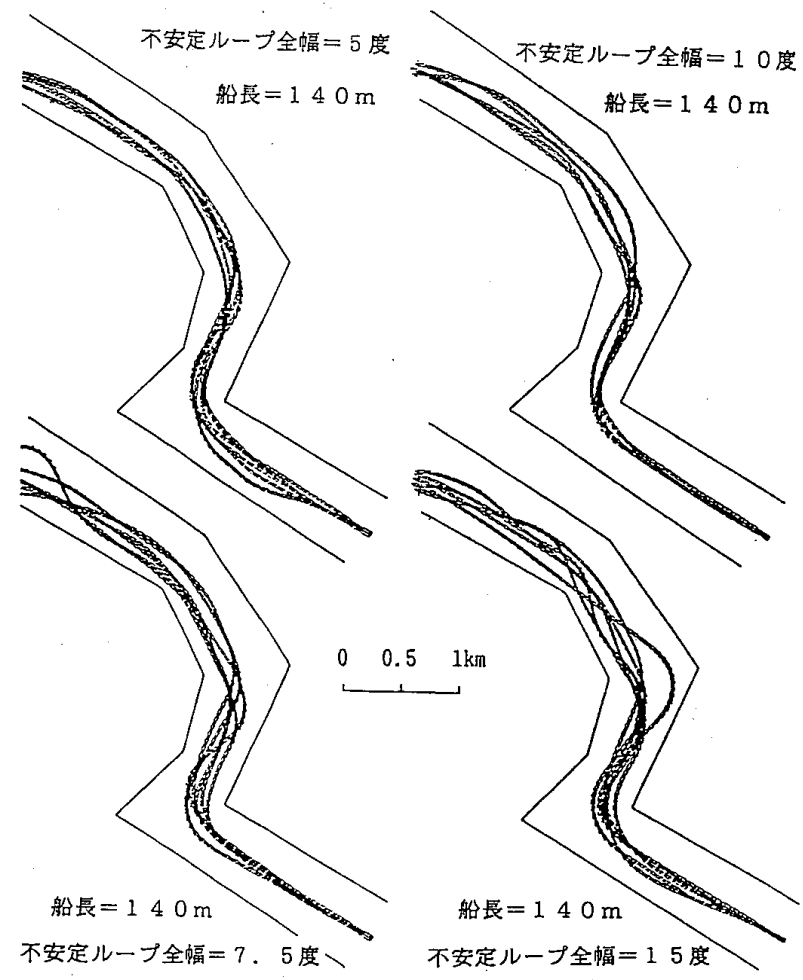

図 4 狭水路通過シミュレーション時の航跡

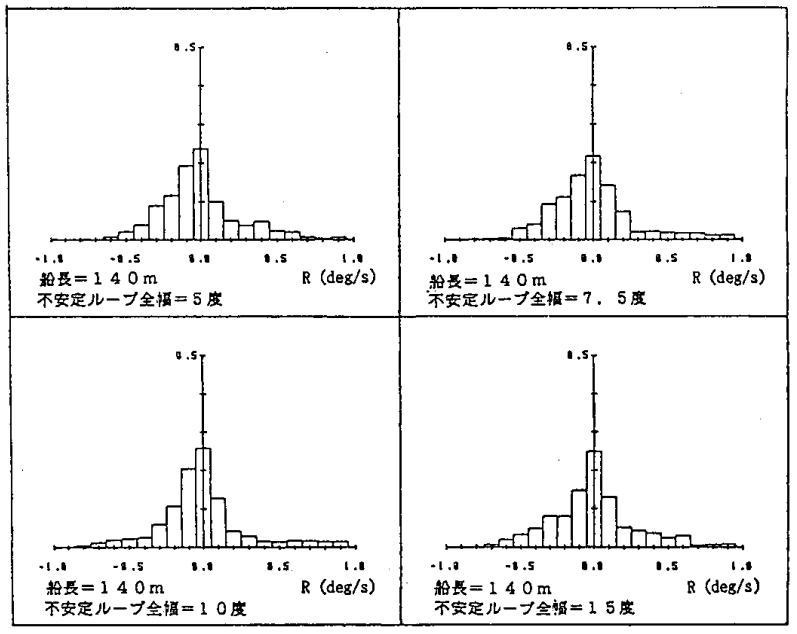

図 5 狭水路通過操船中の回頭角速度の分布 (6人のパイロットの平均)

性能が変わっても一定の望ましいコース上を航行しうるとか，一定以下の操作量の範囲で余裕を残して操船可能 であるとか，きわめて常識的な検討を行った。以下，評価結果を要約して述べる。

（1）最初に検討すべきは，船はどの様な航跡で狭水路を通過したかであろう。図 4 は各供試モデル毎に狭水路 通過時の航跡，6例を重ねてプロットしたものである。但し，ループ全幅が7. $5^{\circ}$ の場合は，通過すべき航路の 勘違いが 1 例あり， 5 例のみ示している。水路中のどの部分を通過すべきかは指示されていないので，ぞの部 分を通過するかはパイロットの自由ではあるが，一見して，ループ幅が 5 の場合には， 6 人の操船者ともに概 略, 航路中央に近いスムーズな航跡を得ていることがわかる。しかし，船の性能が針路不安定になるに従い， 望むとおりに航路中央を航行できず，航跡のバラッキが顕著になり，しかも，不必要な蛇行を伴っていること がわかる。パイロットの指摘によれば, 遭遇船がある場合には, 本船の行動意図が誤解される可能性があり,

このように蛇行すると大変に危険といらことである。

（2）航行中の回頭俑速度の分布を図 5 に示す。この結果は 6 人のパイロットの平均を意味しているが，このよ うなとストグラムの形で見る限り，顕著な差はないようである。回頭角速度の自乗平均值を求めたが，この結 果にも，針路不安定の程度の湿著な影響はないように見觉る。

（3）この操船をする際に，パイロットが発令した舵角の分布を図 6 に示す。6人のパイロットの平均であるが， 針路不安定の程度が強くなると，大きな当て舵が使用されるようになるのが顕著である。ループ幅が $5^{\circ}$ のモ デルの場合, $20^{\circ}$ 以内の舵角で操船しているが, 最大舵角の当て舵の発令が7. $5^{\circ}$ から生じはじめ, $15^{\circ}$ の場合 では普通のことになっている。船の回頭運動を止めるための当て舵の効果が，回頭運動によって誘起される負 の旋回抵抗モーメントによって相殺され，小さな舵角では注とんど効果が期待できず，結果としで最大舵角が 採用されることになる。通常の航行中に $15^{\circ}, 20^{\circ}$ 程度の舵角で航行できれば, 残りは操作量余裕として確保で きることになるが，ループ幅が $10^{\circ}$ 以上ではこの余裕がなくなると評価される。

舵角の自乗平均值を求めた結果を実施順に示したものを図 7 に示す。針路不安定が強くなると，この自乗平均 值はわずか増加する傾向が見られる。増加量は少ないようにも見兄るが，当て舵を発令している時間の割合が多 くないからである。

針路安定性の影響が回頭角速度ではなく，舵角に顕著どなるのはヒューマンオペレータの一般的な特性で，あ 


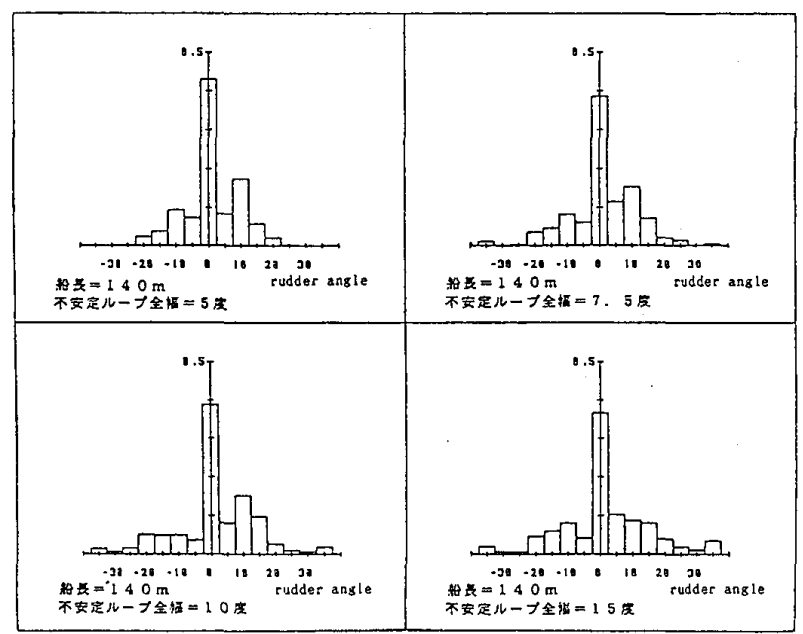

図 6 狭水路通過操船中の舵角の分布 (6人のパイロットの平均)

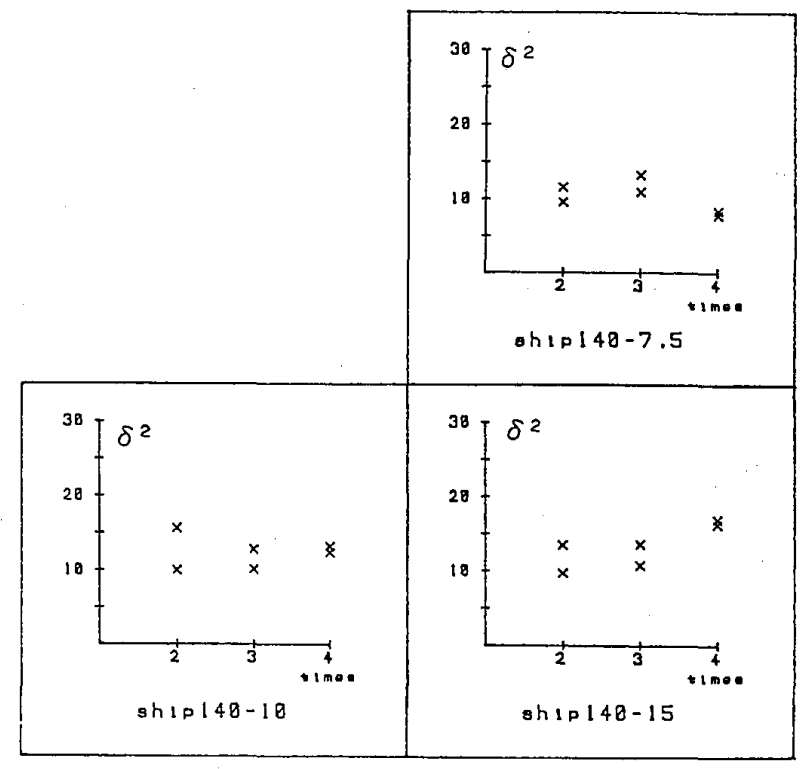

図 7 狭水路通過操船中の舵角の自乗平均値

る程度の性能の低下は制御面で補償するということである。

2.4 シミュレーション結果とパイロットの評価との相関

操船シミュレーションに参加されたパイロットの供試モデルの性能に対する評価はモデルの特性をよく把握し た上で成されて抢り，設定した性能とよい相関を保っていた。また，操船結果にも性能の影響が現われており， 針路不安定が強くなると, 蛇行をしながら誘導され, 航跡が人により, 時により変わる結果になり, 当て舵の効 きを確保するために最大舵角の適用が顕著に増加し，操作量の余裕が減るという結果を得ている。ここで，パイ ロットによる主観的な評価と操船結果の評価との相関を確認して掠きたい。

さて，図 8 は使用舵角の自乗平均値とパイロットに よる性能評価の相関を示したものである。操舵量の增 加とパイロットの感じる操船の困難度は明瞭に対応し ていると指摘できる。この操舵量の増加は最大舵角の 当て舵を適用する頻度の増加によると考兄てょい。回 頭角速度の自乗平均值とパイロットによる性能評価の 相関も求めているが，回頭角速度の自乗平均值には性 能の影響が顕著でなかったから, 当然ながら, パイロ ットが感じる操船の困難度との相関も明確でない。

以上の結果は当然の傾向であろう。人間は船の性能

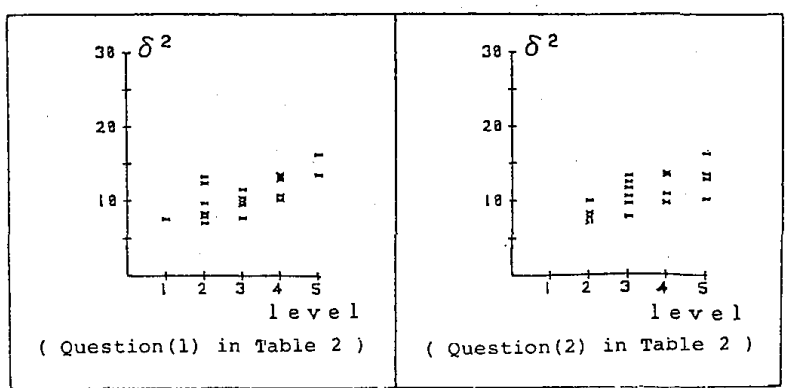

図 8 狭水路通過操船中の舵角の自乗平均值と操船者 の感じる操船難易度の評価との関連 が変わるとその性能変化を補償するように特性をかえる。その結果, 船の性能变化の影響は操作量にすず, 現わ れ，制御の結果である操緃運動に顕著な影響がでるのは人間の制御限界を越えてからというのが通例である。こ の意味で, 今回の操船シミュレーションに用いられたモデルの性能は, パイロットによる狭水路通過に必要な船 首方位の制御が全く困難というには至っていないと指摘できる。しかし，操作量に余裕が残らないという形で, 性能不足と評価されていることになる。

2.5 漁網回避操船シミュレーションの結果

今回の操船シミュレーショソでは航路内に展帳された漁網を回避するといらシナリオが含まれている。狭水路 通過の場合はあらかじめ海図等で確認した水路上を予定の通りに航行可能かが課題となるが，この漁網回避操船 シナリオでは, 近くに到着し，はじめて視認できる障害物を臨機応変に回避する必要がある。したがって，どこ まで自在に船の回頭運動が制御できるかが課題になるるこの目的のために，パイッッには海上交通センターか ら漁網が展開されていると知らされているが，その具体的な配置の情報は提供しないことにし，しかも，3種類 


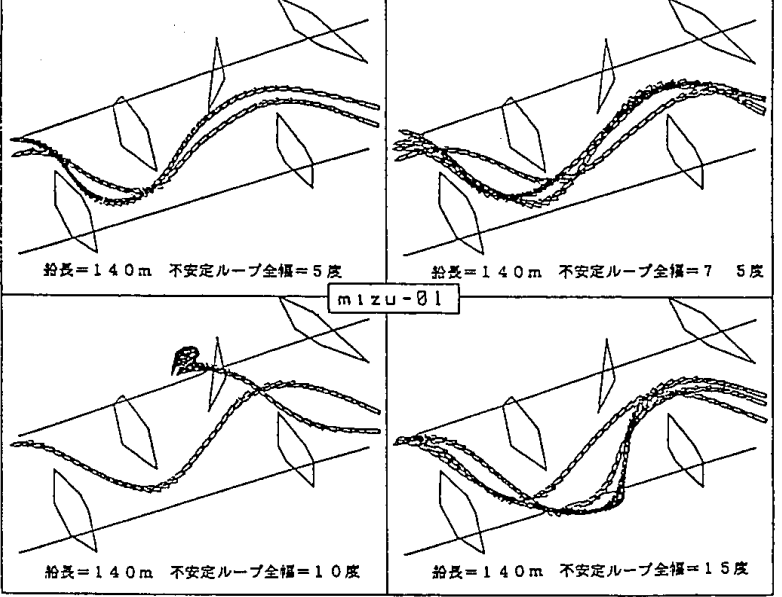

図 9 漁網回避操船中の航跡 (パターン mizu-01・ループ幅別)

の配置パターンを作り，事前のシミュレーションで馴 れることがないように配虑した。

図 9 はある漁網配置パターンに和ける船の通過航跡 であり，針路不安定度の違う供試モデルごとに示して いる。シミュレーション例が少ないこと，また，シミ ニレーション区間が比較的に短いから，初期のアプロ 一チ位置の影響が大きいこと等から，この操船に执い て許容される供試モデルの性能の範囲を結論づけるの は困難である。しかし，針路不安定の程度が増加する と，次第に意図するようなスムーズな回避行動がとれ なくなっていることを指摘できょう。針路不安定な船 では，一度回頭運動が発達すると当て舵によって抑制 することが困難になるから，行き過ぎを恐れて十分に 回頭運動を発達させられない，反対に当て舵のタイミ

ングが遅れ，過大な回頭を生じる等の為である。

狭水路通過操船の場合と同様に, その操船時の回頭角速度や舵角の分布, 両者の自乗平均値等の算定も行い, 不安定の程度が増加すると最大舵角の発令が多くなるといら傾向が指摘できる。今後，この操船に拈ける針路不 安定の許容限界を求めるには, シミュレーション例を増やすこと, 操船区間を延長すること, 潮流等の外力影響 を加觉ること等が考慮される必要があろら。また，航路上に展開された漁網の回避は交通安全上，重要な問題に なっているが，シミュレーション手法を用いて，生じる危険を定量化できる可能性も考光られる結果である。

\section{6 針路不安定の許容限界に関する考察}

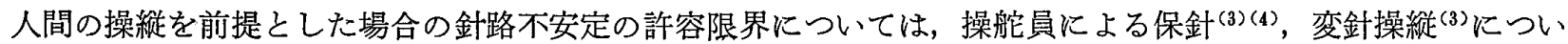
てすでに検討例がある。変針操縦についてはまだ許容限界が明瞭になるに至っていないが，保釬時については人 間の制御の特徵と限界がわかっている。その結果によると，保針の限界は閉ループ制御系の安定問題と考劣るこ とができ; 船, 操舵機, コンパスの部分の位相遅れの極小值が安定性を支配し，それが人間の進めることが可能 な位相補償量, $30^{\circ}$ 以内にあれば，保針可能となる。この意味の位相特性は船の操縦性能の他に，船の大きさに 依らずほぼ一定にされている操舵機の時定数に大きく依存し，運動のテンポの速い船ほど，遅れ量が大きくなる。 従って，保針に打壮る針路不安定の許容限界は運動のテンポの速い，L／Vの小さい船ほどシビアになる。野本 は針路不安定の許容限界を不安定ループ全幅と $L / V$ の関係で示している(5)。

図10は本研究の供試モデルの針路を安定に制御するために、コントローラとしての人間が補償しなければなら

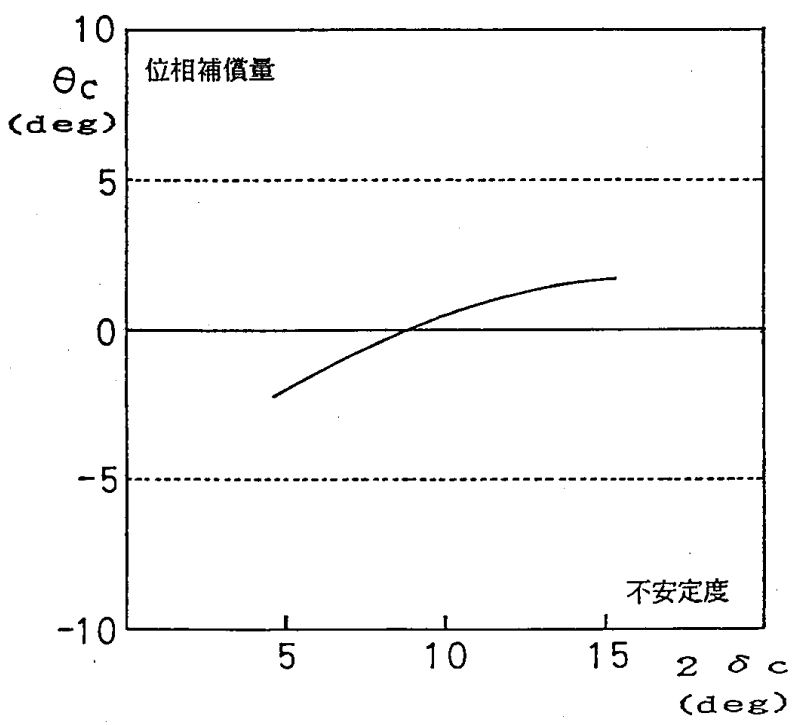

図 10 供試モデルの位相特性 ない位相進みの特性を表す。狭水路通過操船シミニレ

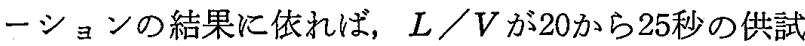
船の場合，ループ全幅で $7.5^{\circ}$ になる，相当に操縦困 難と評価されている。この場合に必要とされる位相補 償量は数度程度であり，30度程度の位相補償が可能な 操舵員による保針に較べて相当に厳しい評価となって いる。操舵員は長期間，その船に乗船し，船の特性に 岶熟できるが，パイロットは乗船後，すぐに操船指揮 をする必要があり，人間の持つ習熟効果が期待できな いことも原因と考克られよう。しかし，本質的には， 操舵員は針路のみの制御に専念できるが，パイロット は船位を同時に制御する必要があるという点に困難が 生じると考えるべきであろう。針路に較べて，船位は $90^{\circ}$ だけ位相が遅れるから，船位に着目した操縌を強 めるほど，操舵の位相は遅れがちになることは避けら 
れず，その結果として，パイロット操船に招いては，操舵員の保針の場合以上に良好な針路安定性が要求される と考觉られる。

また，不安定が增加すると，位置制御が強められないところから，図4 亿見るように，誘導軌跡が広く分布す る結果となるのであるう。この意味で，人間の位置制御能力自体の調查が将来の課題となる。

しかし，操船限界を上述の上うな制御系の安定性から判断するのみでは不十分であろう。不安定船が回頭運動 をすると，それを助長する方向に旋回抵抗が作用するから，回頭を止めようと当て舵を適用してる，その効果の 相当部分がキャンセルされ，通常汇適用される15度程度の当て舵では十分な効果が期待できなくなる。そこで最 大舵角の当て舵の適用がなされる結果となるが，この場合には制御量の余裕はないことになり，操船者には相当 の不安を与えることになる。著者の一人が公表している変針操船限界に関する考光方は，有限の操作量という見 地が取り入れられて扣り, この面からの許容限界の定量的把握が課題となる。

\section{3. 結 論}

本研究ではパイロット操船という観点から，船の操縦性能の中で重要な位置を占める針路不安定の許容限界を 調べるために，広島大学の港内操船シミュレータを用いて，系統的な操船シミュレーションを実施した。この中 で，針路不安定と操船の困難度との対応が比較的に把握しやすい狭水路通過操船を主とする結果を要約すると， 以下の結論を得る。

（1）本研究で実施したような操船シミュレーションは, 針路不安定の許容限界を調べるという等, 人間を含む 操縱システムの解明有効な手段である。

（2）操船者は設定された船の性能を与兄られた視界，コンパス等の情報から的確に把握しており，設定した性 能とパイロットの理解は良い相関を示して打り，信頼するに足る操船シミニレーションになっていたと指摘で きる。

（3）湾曲した狭水路を誘導する際，針路不安定な船は当て舵の効きが十分でないために，操船が困難になる。 実施したシミュレーションシナリオは水路幅も相当に広く，外力も僅かであり，交通流も想定していないから， 明らかに操船不能という事態には至っていないが，不安定の程度の増加に従い，目標とするコース上に船を誘 導するのが困難になり，蛇行を伴ったり，頻繁な最大舵角の発令を余儀なくされて扣り，現実に運航されてい る船の中で針路不安定の程度の高いるのでは操船上の余裕はすでに失われていると指摘できる。

（4）パイロット操船という立場からの針路不安定の許容限界は相互連携動作である海上交通流の中での避航の 安全性の判断とか，生じるかも知れない危険を確実にクリヤーしうる余裕の確保等を不可欠として招り，それ らを考虑したパイロットの操船感覚から見た許容限界は, この大きさの船に対して, 不安定ループ幅にして5 ${ }^{\circ}$ 〜 10 以下の範囲にあると指摘できよう。しかし，この範囲をより絞り込むためには，むっと現実的な条件， 例光ば交通流，複雑な外力条件等を考慮したシミニレーションや実操船との比較が必要となる。これらの一部 は別の機会に報告される予定である。

この研究は日本パイロット協会と広島大学で共同して実施したものである。この研究は船の持つべき最低限の 操緃性能，操縦性能基準を確立するためになされた，日本パイロット協会技術委員会操綎性小委員会，日本造船 研究協会R R742 委員会で実施されつつある一連の研究の一部であり, その過程で両委員会の委員各位の助言と 協力を戴いた。特に, 兩委員会の委員である住友重機械(株)の芳村康男博士, シミュレーションに参加戴いたパ イロットの各位, また, 種々の助言と援助を戴いた弓削商船高専の野村士平教授, 海上保安大学校の寺本定美教 授, 長澤明助教授, 日當博喜講師, 大島商船高専の岩崎寛希講師, 広島大学工学部の浮体運動学研究室の平尾三 郎助手, 学生諸氏の貢献に対して, 深甚の謝意を表する次第である。また, この研究に対して, 文部省科学研究 費補助金の交付を得たことを記す。

\section{参 考 文 献}

(1) T. Nobukawa, T. Kato, K. Motomura, Y. Yoshimura: "Studies on Maneuverability Standards from the Viewpoint of Marine Pilots", Proceedings of MARSIM \& ICSM 90, 1990.

（2）小瀬邦治, 平田法隆, 平尾三郎, 大橋克海, 浜田康弘：出入港操船シミュレータ, 日本航海学会論文集, 
79 号, 1988年

（3）小瀬邦治注か：出入港時の要素操船性能について, 第一報, 第二報, 第三報, 日本航海学会論文集, 74号, 81 号, 82号, 1986年, 1989年, 1990年

(4) T. Koyama, K. Kose. K. Hasegawa : "A Study on the Instability Criterion of the Manual Steering of Ships", Journal of the Society of Naval Architects of Japan, Vol. 142, 1977.

(5) K. Nomoto: "Some Aspects of Simulator Studies on Ship Handling", Proceedings of the PRADS-International Symposium on Practical Design in Shipbuilding, 1977.

\section{質 疑 応 答}

本田啓之輔(神户融船大学)：設定水域における針路不安定許容限界を検討する場合，コースライン上の保針操船 の許容限界を見る問題とは異なり，水路幅，水路長，変針角，変針回数といった変位量が操船限界に影響する 重要な因子になると思われます。今回のテーマの検討では，水路諸元を入れた評価手法についてどのよらに揖 考えですか。

小瀬邦治：この研究で検討対象とした操縦性基準はどのように船にも最低限, 必要とされる性能といら意味です から，特定の水路を想定すると，そのよらな水路を通過する必要のない船に対しては過酷な要求になる危険が あります。しかし，港湾や水路域での操船を考えないで，基準を作ったのでは，安全上，もっとも重要な局面 の検討が欠けることになります。そこで，操縦性基準を求める立場は，幅とか，広さとかに関係なく，港湾や 水路域で操船される場合に，必要とされるような操綎運動が人間の制御下で可能な操縦性能と考えるべきとし ています。

有限の幅の水路の通行が船の性能に応じて, ぞの程度，困難になるかという問題は重要と考皇ますが，本研 究は上記の意味で，水路幅の制約は考皇ないとら立場から検討しています。従って，水路幅の制約が問題に ならないよらな幅を選んでシミュレーションしたつもりです。水路諸元を考虑した安全性評価法については， 別の問題として検討したいと考えています。

飯島幸人(東京商船大学)：水路の通航難易度を相互比較できるような係数を Relative Risk Factor (RRF) と いらもので表わしている論文が PIANC で論議されています。この論文にはR R F の導出方法は書かれてい ませんが，もし御存じならばお教え下さい。

小瀬邦治：本田教授への回答において述べをしたように，今回の検討は水路の通行の可否を論じると言うより， 水路等を航行する際に最低限，必要となる操縦，つまり，必要とする回頭運動を人間の制御下で自在に設定可 能か否かに着目して行っています。特には, 回頭運動の制御能力を保針や変針といら特定の制御パターン下の みではなく，より自在な運動に対して調查すると言らことで，その典型として湾曲した水路といら考えを取り 入れています。そらした観点から考えましたので，水路の通航難易度を比較する R R F 等の概念の導入は考劣 ていませんが，十分に余裕のある水路の通航の難易度といら観点から，今後，そうした手法の導入による評価 の定量化を検討してみたいと存じます。 